\title{
AN ASSESSMENT OF WASTE MANAGEMENT OPERATION IN MALAYSIA: CASE STUDY ON KUALA LANGAT AND SEPANG
}

\author{
Innocent A. Jereme \\ PhD Student, Institute for Environment and Development (LESTARI) \\ National University of Malaysia (UKM), Malaysia \\ E-mail: innoviva2001@yahoo.com
}

Chamhuri Siwar

Emeritus Professor, Institute for Environment and Development (LESTARI)

National University of Malaysia (UKM), Malaysia

E-mail: csiwar@ukm.my

\section{Rawshan Ara Begum}

Institute of Climate Change (IPI)

National University of Malaysia (UKM), Malaysia

Md. Mahmudul Alam

PhD Student, Institute for Environment and Development (LESTARI)

National University of Malaysia (UKM), Malaysia

E-mail: rony000@gmail.com

\section{Citation Reference:}

Jereme, I.A., Siwar, C., Begum, R.A. and Alam, M.M. 2015. An Assessment of Waste Management Operation in Malaysia: Case Study on Kuala Langat and Sepang. International Journal of Environment and Waste Management. Vol. 16(2), pp. 133-144. [Online Link]

This is a pre-publication copy.

The published article is copyrighted by the publisher of the journal. 


\title{
AN ASSESSMENT OF WASTE MANAGEMENT OPERATION IN MALAYSIA: CASE STUDY ON KUALA LANGAT AND SEPANG
}

\begin{abstract}
Malaysia has seen a high rate of economic growth in past couple of decades hand in hand with an ever increasing size of population. Consequently, the issue of sustainable waste management has become an important priority for policymakers and other stakeholders of the society. Although the respective local administrations are responsible for collection and disposal of household and industrial wastes, privatization of the entire process has been heavily promoted and pursued by the federal government of the country. A significant number of waste dealers - both formal and informal - are currently involved in the field level. Through analysing the inputs acquired from semi-structured interviews with these waste dealers operating at Kuala Langat and Sepang districts in the Selangor state, this paper attempts to identify the roles they are playing in the overall waste management cycle, the challenges they are facing, and the untapped opportunities from their operations. This paper will help the policy makers, waste management strategists, local administrators and researchers in the field to formulate sustainable policies, and identify further areas of study in the relevant field.
\end{abstract}

Keywords: waste dealer/operators, waste management, recycling, informal sectors, scavengers, landfills

\section{INTRODUCTION}

The issue of waste disposal management has recently gained widespread attention in virtually all states of Malaysia. With the communities facing rapidly increasing disposal costs, the opinion leaders denouncing the amount of materials being thrown away as environmentally and ethically unsound, the lawmakers struggling for sustainable solutions - pressure is mounting on manufactures and packagers of consumer goods to minimise the amount of refuse. Amidst these changing circumstances, some laws have recently been passed making waste management a national issue in Malaysia and many others have similar laws on their agenda (Yahaya 2007a).

Hand in hand with the high rate of economic growth in the past few decades, the population of Malaysia have grown from 21,793293 in 2000 to 28,339273 in 2010/11. Considering these economic and population growths combined together, Malaysia is generating more wastes now in comparison to any previous point of time in history. It is estimated that about 18,000 tons of wastes are generated in Malaysia per day and this figure is expected to increase at the rate of $2 \%$ every year. Out of these, $75 \%$ of the wastes generated are collected and disposed at dumpsites or landfills that are not sanitary. In Kuala Lumpur, only 5\% of the wastes generated in the city are recycled and the rest goes to landfills (Yassin 2006).

As of April 2007, there were 291 landfill sites in Malaysia to dump wastes, out of which only ten were sanitary landfills; of these 291 sites, 112 were closed and the remaining 179 were still in operation. It is expected that solid waste generation in Malaysia will reach 30,000 tons per day in 2020 (Yahaya 2007a). A waste minimisation study conducted by the Local Government Authority indicates that food waste and other organic waste constitute $47 \%$ of the total wastes generated, followed by paper $15 \%$, plastics $14 \%$, and others constitute the 
rest (Yassin 2006). In 2020, there is target to recycle $20 \%$ of the total wastes generated, $15 \%$ for intermediate processing and the remaining $65 \%$ to be deposited at various landfill sites. Besides, the existing legislations on waste management were reviewed to improve solid waste management by privatising it and to increase recycling awareness in the country (MHLG 2003).

This alarming situation in waste disposal management prompted the Malaysian Government to launch the $6^{\text {th }}$ Malaysia Plan (MP) for 1991-1995, with an emphasis on diversifying the sources of growth of the wastes. The $7^{\text {th }}$ Malaysia Plan (MP) for 1996-2000 also focused on the quality of life and environment. As the population continued to grow and available lands were becoming scarce for acquiring landfill sites due to opposition by residents and community leaders, in the $8^{\text {th }}$ Malaysia Plan (MP) for 2001-2005, a National Recycling Program was re-launched with these objectives as follows:

a. Inculcate the habit of recycling among the population;

b. Reduce operational cost of solid waste management;

c. Minimise the volumes of waste disposal by landfills;

d. Reduce utilisation of raw materials; and

e. Improve awareness and cooperation among stakeholders (MHLG 2003).

Under the $9^{\text {th }}$-10th Malaysia Plans and with the implementation of the Solid Waste Management Bill, the recycling and disposal of solid waste will be privatised in order to improve services, relinquish financial burden and include the private sector. These concessionaries are responsible for collection, storage, transportation, treatment and recycling of all of the country's non-hazardous wastes (Market Watch 2011).

Malaysia started privatising its waste management operations in 1994 (Budzik et al. 2002). Gradually, waste collection and public space cleansing services are being taken over by Alam Flora Sdn Bhd. In order for the process to be implemented smoothly, the consortia were instructed to take over the solid waste management over an interim period. The full-fledged privatisation is yet to be determined by the government, pending legislation based on the new National Waste Bill (Hassan 2002). Until the privatisation is fully implemented, most aspects of solid waste management will continue to be in the realm of the Local Government.

Although the current large-scale privatisation entails a more comprehensive transfer of activities and functions than the previous semi-privatisation measures, the public sector cannot transfer all responsibilities to the private sector. Since the waste management privatisation was initiated at the national level, the Federal Government will be responsible for ensuring that the consortia conform to the standards, and rules and legislation as stipulated by the Government. The Department of Local Government at the Ministry of Housing and Local Government (MHLG) will be responsible to oversee the compliance level of the private sector consortia, while the Department of Environment (DOE) will be responsible in the area of general pollution control and Environmental Impact Assessment (EIA) of waste treatment facilities (Hassan 2002). After signing into the law in 2011, the Federal Government has now taken over management of solid wastes with the creation of National Solid Waste Department.

For Ministry of Housing and Local Government (MHLG), the role of local authorities will remain central in terms of enforcing laws and regulations and ensuring that the private sector meets required standard and quality (MHLG 2003). As part of the privatisation process, collecting the fees for the waste management services is no longer the direct responsibility of 
the local authorities but of the waste management company. The particulars of this financial aspect of the waste services have not been addressed yet, but as the fee is not planned to be included in the semi-annual assessment rates imposed by the local authorities, a separate fee needs to be introduced. The introduction of such a fee may meet some political and public opposition in Malaysia (Hassan 2002). Under the backdrop of this political undertone, the fees have not been settled till date because the citizens are not willing to pay for any perceived unseen service.

The interim period status of the solid waste service provision has resulted in uncertainty for both the concessionaires and the local authorities. In particular, the impending National Waste Bill and the issues of service fees are creating some negative implications with regards to further development and final realisation of the privatisation process. It can be argued that these uncertainties pertaining to a reluctance to invest in new resources and equipments by various stakeholders have resulted in a relatively short-term planning. Under the backdrop of these background information, this study explores to understand the waste management operations and its problem and prospects in Malaysia.

\section{METHODOLOGY}

\subsection{Study Areas}

This study was conducted on two district areas - Kuala Langat and Sepang - from Selangor state in Malaysia. Kuala Langat was established as a district on January 1, 1977 under the Local Government Act. It is situated in the western part of Selangor, bordered by the district of Klang to the north and Sepang to the east. Its southern border forms part of Selangor's border with the state of Negri Sembilan. The state of Melaka forms its western borders. The major towns in Kuala Langat are Banting, Bandar Baru Tingi and Telok Datok, the district capital. It had a population of 222,261 in 2010. Kuala Langat is famous for its agricultural products, industries that recycle scrap metals, home stay programmes for tourist and the National Space Centre in Kanchong.

Established as a district on January 1, 1975 and situated in the southern part of Selangor, the district of Sepang, on the other hand, is the youngest district in the state of Selangor Darul Ehsan. With a population of 212,050 in 2010, the district of Sepang is best known for hosting the Sepang International Circuit and the site of Kuala Lumpur International Airport. 


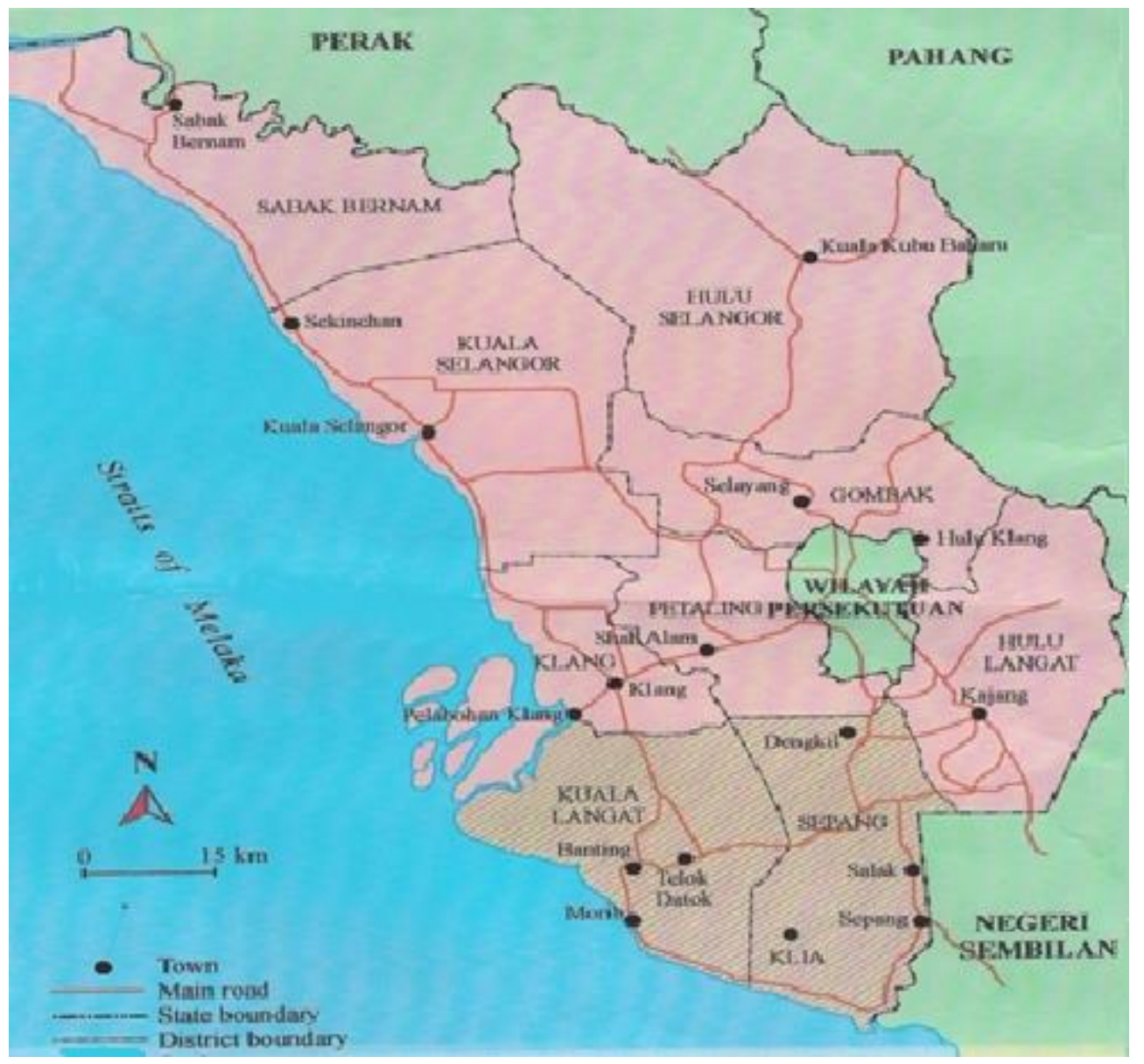

FIGURE 1.Map of Selangor showing Kuala Langat and Sepang

Source: Malaysia National Atlas 1977

The organisational structures of the districts of Kuala Langat and Sepang are the same as all the 18 municipal district councils in Malaysia are headed by the Yang Di Pertua (YDP) or Municipal President, while the municipal secretary heads the various municipal departments. The councils consist of 24 individual members (known as Councillors) who are all appointees of the state government. The general responsibility of the day-to-day operations and administration of the municipality rests with the Yang Di Pertua (YDP) or Municipal President. The secretary of the Municipality and several departments' heads assist the YDP in the day-to-day operations and administration of the municipal council's activities.

\subsection{Data Collection}

The primary data were collected through interviews. The outline of the questionnaire was prepared in advance, though the order of the questions was decided during the course of the interviews. The reason for choosing relatively semi-structured interviews was to allow the possibility to be flexible and to adjust the questions to each of the informants. In addition, the researcher also wanted to be open to the possibility of obtaining other information from the respondents that could be of interest to the study.

Semi-structured interviews were conducted with recycling operators in Kuala Langat and Sepang districts to obtain information about the activities that the enterprises carried out, and the enterprises' experiences, opinions and feelings concerning their activities and problems 
they usually encountered with the districts councils. In addition, there were further interviews with Majlis Perbandaran Sepang and Majlis Dearah Kuala Langat district officials at Banting, private waste dealers, as well as with Alam Flora official at Cyberjaya that is the sole concessioner collecting and disposing of wastes in these districts. These interviews were conducted to gain information about the current solid waste practices and waste recycling activities in Kuala Langat and Sepang.

\section{WASTE RECYCLING PROCESS}

The respective Municipal Councils are responsible for the waste management of Sepang and Kuala Langat; however, the daily collection of wastes from house to house has been outsourced to Alam Flora Sdn. Wastes are collected from residential houses and apartments three times a week, while they are collected from markets and sweeping of roads on a daily basis. In Sepang, the wastes collected were sent to Ampang Tenang landfill in Dengkil and Sungai Sedu landfill. According to the officer in charge of waste management, starting its operations in 1990, the Sungai Sedu site was closed at the end of 2009 as it reached its full capacity or lifespan. After the closure of Ampang Tenang, the other landfill site, all the wastes collected from Sepang will be sent to Tanjong 12 landfills in Kuala Langat as alternative sites.

The wastes collected from Kuala Langat are sent to the landfill in Tapak Pelupusan Sampah Sungai Sedu, which was built in 1996 and is currently managed by Alam Flora Sdn Bhd. The Selangor state government is building a new landfill in South Kuala Langat at Bukit Changang which will serve the districts of Kuala Langat, Sepang, Kajang and Bangi after its completion. Additionally, a proposed privately managed landfill site, Southern Landfill, is currently under consideration.

\subsection{Waste Recycling in Kuala Langat and Sepang}

The district council of Sepang launched an action plan to create recycling awareness, called "Local Agenda Program 21", in 2006. For the campaign, the whole district was divided to 24 zones; each councillor in his/her respective zone supervised the initiative and reported back to the district council. According to the officer in charge of waste management at the district council, the aim of the program was to inculcate recycling habit into the lifestyle of people.

The district council also introduced source separation at the household level by distributing free plastic bags in four colours to households for separating their wastes - yellow plastic for aluminium, red for plastic waste, white for food waste and purple for waste papers. The representatives of Alam Flora Sdn Bhd visit the households on a weekly basis to collect these wastes and pay the households after weighting the quantity. Although it was not included in the contractual agreement, Alam Flora is doing it as part of its corporate responsibility to the community with the objective of encouraging the households to always recycle their wastes.

However, lately this idea of giving out plastic was discouraged; shopping malls in the area are now required to give out reusable/biodegradable bags for shopping, while households who insist on having plastic bags need to pay a surcharge. The idea is to discourage the local population from using plastic bags in their daily shopping. There are three recycling centres in Sepang - Taman Kota Wawasan, Putra Perdana and Pantai Sepang Putra - which are managed by the district council. Kerbsides recycling were introduced at schools and some 
residential areas as the recycling centres are located far from homes and schools. Small and medium enterprises (SMEs) in Cybarjaya such as HSBC, DHL, Dell and Motorola have introduced in-house recycling centres in their respective business premises. Moreover, a mobile recycling centre will be built at the district office of Cyberjaya to collect wastes from local people who will be paid 10 cents per kilogram of waste brought to the council. There is also a call centre for collecting wastes at the district where households and offices receive calls from locals who want them to collect their waste. After sorting, all the recyclable waste materials collected in Sepang are sent to the paper mills and aluminium companies of Kajang to be used as secondary raw materials.

Kuala Langat, on the other hand, built nine recycling centres in the district which are located at Pasar Besar Banting, Taman sri Muda, Tanjung Sepat, Methodist English School, Taman Sri Putra, Sekolah Menengah Jenjarom, Taman Sri Medan, Pantai Morib and Telok Panglima Garang. These recycling centres are managed by the district council. Starting from 2006, recycle bins were provided to the secondary schools of the district to separate the wastes collected from these schools. A waste vendor was contracted to collect these wastes from the schools but this program failed in the district even with advertisements in radio and television because students prefer to take their wastes to private recycling business operators for a higher rate. The recycling centres of the district were failures as well, because the local people failed to bring recyclable materials there. According to the officer in charge of the district, apathy and ignorance regarding recycling were the main reasons behind this failure.

\subsection{Recycling Operations in Kuala Langat and Sepang}

Recycling operators - dealing with scrap metals, papers and plastic containers - can be seen on both sides of roads from old Klang bus terminal to Banting town, as well as along Dengkil and Bandar Baru Salak Tinggi. Kuala Langat is noted for its formal and informal scrap metal business operators, resulting a good business opportunity for these recycling operators. Informal scrap metal business here refers to the activities that are not duly registered or recognized by the local councils, whereas the formal ones are registered and recognized and their activities are monitored by the local councils in their respective locations.

There are 42 registered recycling operators in Kuala Langat and 17 in Sepang. Additionally, according to the district officer in charge of waste management at Majlis Daerah Kuala Langat (MDKl), more than 50 unregistered operators are operating in both the districts. Located mostly at Dengkil near Banting, the majority of the waste dealers in Sepang numbering 14 - deal with tear substances like aluminium, paper, plastic and metals, while the remaining three deal with both industrial wastes and tear substances. The location of these dealers at Dengkil are dependent on the land space available and its proximity to Amsteel and Megal Steel, which are the two main sources of waste materials. Based on contractual agreement with the steel companies of the area, the waste dealers collect their wastes on daily or weekly basis, sort out the recyclable materials and dispose the residue in nearby landfills. Waste dealers caught by the district council for dumping illegal wastes could have their operation license not renewed and also asked to pay fine - depending on the quantity of wastes disposed; however, no official account of illegal dumping by illegal waste dealers could be obtained.

\subsection{Collection and Transportation of waste materials}


The waste dealers collect their waste materials from households and manufacturing companies - like Toshiba and National Electricity Company (NEC). They deal with these manufacturing companies directly on contractual basis and collect their wastes - mostly dry wastes - either on a weekly or bi-weekly basis, against a payment of RM500 for every tonne of wastes collected. Wet wastes, on the other hand, are collected by the local councils for composting. For carton box wastes, the waste dealers buy them from factories at the rate of 10 cents per kilogramme and sell them at the rate of 30 cents. They also drive around the local communities from time to time and collect wastes from households at the rate of RM3.50 per kilogramme for aluminium, 40 cents per kilogramme for paper, 70 cents per kilogramme for metals and RM18.00 per kilogramme for copper. The local community is also participative in exchanging wastes for money regardless of the races or age groups. However, the female members of the community seldom bring in their wastes to exchange them for money. After collection, the wastes are sorted manually according to their categories of trade.

The separation of wastes is labour intensive, so local people seldom work with the waste dealers as employees. As a result, most waste dealers here employ foreign workers from India, Bangladesh, Indonesia and other neighbouring poor countries to sort the wastes for them. According to the officials of the two district councils, on an average five workers are employed by each dealer. Indian communities are the dominant group in this enterprise, followed by the Chinese and then the Malays. The dominance of the Indians in this trade may be linked to their exposure with the waste management concessioners like Alam Flora Sdn Bhd and others in Malaysia, which makes it natural for them to join the trade after acquiring some experience in addition to the fact that a small sum of capital is needed to start the business.

After separating the recyclable materials, they are sent to different destinations as secondary raw materials, like metals are sent to Amsteel Company in Bukit Raja and Megal Steel in Olak Lempit in Dengkil, the carton boxes are sent to Senyan in Dengkil, and the remaining materials are exported to China or India. The waste residues are deposited at Sungai Sedu deposition field in Banting or at Tangung Dua Belas. With regard to the lorry cost, waste dealers pay RM25 to the local council for one tonne of lorry and RM45 for three tonnes of lorry after separating the wastes and before their disposal. Hazardous wastes attract as much as RM800 for disposal by waste operators.

\subsection{Roles of the Informal Sector (Scavengers)}

Scavengers, or independent waste pickers, can be seen virtually at every part of the districts collecting recyclable waste materials - using bicycles, motorcycles, old cars and trucks - to be sold to waste dealers. Of the major benefits of this informal recycling network are employment generation, reduction of waste collection and disposal cost, conservation of natural resources, and provisions of raw materials at a comparatively lower cost. Despite these obvious benefits, the contributions of the scavengers are not well appreciated by the government and residents who tend to view them as outcasts, a nuisance and a security threat. Many politicians and residents oppose these informal waste pickers because they interfere with the formal collection and dumping operations (Jindal, 1998). In general, people involved with the informal waste management sector have "very low social and economic standing, because society perceives that dealing with something which is dirty and thrown away by others is demeaning" (Habitat 1994). 
Despite their vital roles in reducing wastes in the districts, there is no data available for the activities of these scavengers. Their activities can be seen at bus stops, bus terminus, wet markets, shopping malls and landfills in Dengkil, Banting, Jenjarom, Bandahsalaktingi and Telok Panglima Garang collecting recyclable materials such as paper, plastic and aluminium cans. Although it may seem odd to many people as it involves picking up rejected materials, it helps create employment to a particular group of the population, consisting of mainly retired and aged people, and teenage boys who dropped out of school or have been abandoned by their parents. It can be soundly estimated, however, that the total number of scavengers are reducing as a result of high economic growth that Malaysia has witnessed in the last two decades.

The informal waste pickers interviewed mentioned that people in general perceive them as drug addicts and mentally derailed individuals. However, in reality they are just like other people of the society trying to make a living to support their families. Most of them are from very poor families and have no skill or education and capital to do other trades.

Because of their contributions to the society, the respective district councils should recognize them and integrate them into formal waste management streams in the districts. Additionally, they can be helped with soft loans so that they can initiate joint partnerships within the trade. However, the young children of these waste pickers should be discouraged from joining this occupation at an early age by giving aid or subsidy so that they can go to schools instead of picking up wastes.

\section{PROBLEMS OF OPERATIONS}

According to the waste dealers interviewed, red tapes in registering their businesses with the local authorities is a major challenge that the trade is facing. The researcher has been told that it takes months, sometimes even years, to get a waste enterprise duly registered. Moreover, there have been allegations of rampant corruption and lobbying, leading many waste dealers operating illegally. The waste dealers interviewed also mentioned that as the Tamil race is dominating the recycling business here, police and local authorities often visit their premises and extort money in the name of "performing duties". In case anyone refuses to give them the bribe, anyhow they find some "reasons" to close the business, allege the waste dealers, prompting some waste dealers to take the decision to leave the trade for good.

In Dengkil and Telok Panglima Garang industrial areas, the customs personnel inspect the waste items against the waste declaration documents of the companies for cross-checking, delaying the daily waste collection activities. There are also allegations of extortions, which increase the overall cost of doing the trade.

Furthermore, the waste dealers have to pay a high disposal fee for waste residues at landfills. Additionally, due to the high rental cost in the districts they have to face some constraints in running their businesses, because as per the policies of the local councils they are obliged to build storage houses for the wastes. In order to reduce the higher rental cost, they prefer to choose sites at remote locations at a lower rate, which contributes to a higher transportation cost. In addition, the short tenancy of land makes running of the business insecure for these recycling operators. 
Besides these challenges, the fact that oftentimes recycled paper is comparatively expensive and as a consequence less people are interested to buy it, running of the recycling business gets more difficult. If compared with products made from virgin materials, some recycling products are usually of lower quality, which restricts the usage of these products and consequently narrows down the markets involved. Although waste materials such as glass textiles, plastic bottles and tires can be recycled, their lower values in the market make them unfavourable for recycling.

The Malaysian industries have a high demand for secondary raw materials, but a lower recycling rate has forced some industries to import recycled materials. Formulation of proper policies addressing these issues and subsidy incentives from local councils are needed to improve the current scenario.

\section{CONCLUSION AND RECOMMENDATIONS}

If operates under a conducive environment, waste recycling enterprises is a viable business. Recycling is a labour-intensive activity with relatively low start-up costs, which provides opportunities for employment and income generation for a large number of people. The informal sector, even though they contribute significantly in reducing wastes, is not considered in any policy formation. Waste recycling often serves as an entry point into the urbanization, providing participants with economic benefits, higher social status, on-the-job training and business opportunities. It helps to reduce disposable cost for local authorities by extending the life span of landfills in the districts, and reduces the need for local authorities to invest in transportation and equipment, vehicles operation and maintenance cost.

It is generally accepted that the usage of recycled materials can save natural resources and thus it is a way to achieve sustainability. Moreover, overall consumption of energy in the economy can be reduced by using recycled materials in the production process. The usage of recycled materials also helps reduce the need for import of raw materials; when separated properly, it is easier to find high quality waste materials from the local market. Considering the fact that many industrial units are located in these rapidly developing districts and its nearness to Putrajaya - the administrative capital of Malaysia - the recycling business here has good economic prospects and potentials.

The Kuala Langat and Sepang districts of Selangor have adopted various measures for waste diversion as most landfills which use the traditional method to dispose wastes have reached their capacities and will be closed very soon. Measurements such as establishment of recycling centres at strategic locations in the districts - like building kerbside recycling facilities at school premises - is a welcome idea even though most of the centres at the communities are underutilized.

However, some of the policies of the local councils are not consistent, which is not comforting to the private waste enterprises that are in waste recycling business in these districts; as a result these enterprises have been affected negatively. Policies are changed without due consultation with those who are affected directly and as such it is an impediment to the growth of recycling enterprises in the districts. Some waste dealers have left the business because of constant disturbances from the council officials and security officials checking for stolen goods sold as scraps by locals. 
Therefore, waste dealers should be consulted with while formulating policies that will affect them directly. Besides, the amounts charged for waste disposal by local councils can be reduced to curb illegal dumping by waste dealers. The local councils can also work on reducing the waiting time for waste dealers to get their business legalised, which may encourage some of the waste dealers who left the trade to make a return to continue their business, which in return may help boost up the efforts of the local authority to reduce indiscriminate dumping by residents. Additionally, the district councils can help the waste dealers get permanent sites from where they should be able to operate their businesses not far from the industrial areas and convenient disposal sites by residents of local areas.

It is expected that the districts of Kuala Langat and Sepang will seriously consider the recommendations that are stated above in order to develop a viable recycling industry in the districts. Finally, turning wastes which currently go to landfills into marketable recycling materials is the only sustainable way forward for these two districts from an effective waste management perspective.

\section{REFERENCES}

Agamuthu, P., Hamid, F.S. and Khidzir, K. 2009. "Evolution of solid waste management in Malaysia: impacts and implications of the solid waste Bill 2007," Journal of Mater Cycles Waste Management, 11: 96-103

Budzik, M. Jonathan,M. Luciano, A. \& Juliana, P. 2002. Waste Management Overseas. The Malaysian experience. Dec.2002

Furedy, C.1997a. Initiative for source separation and urban waste use; Sustainable consumption and Municipal solid waste reduction in Developing Asia countries.Christine Furedy, New York University Canada.

Habitat International, 1994a. Appraisal of solid waste collection and private sector involvement in Dar re Salaam City, Tanzania. Habitat International.29 (2) 353 -366.

Janeen, T. 2004. A case study of a hotel solid waste management in Bali, Indonesia's thesis, University of Waterloo, Ontario Canada.

Jindal, B. 1998. Waste recycling policies in Hong Kong. International Journal of Material Recycling 10 (3), 205-230.

Kwok K. Chong Tommy. 2003. The recycling of Municipal solid waste in Hong Kong, Msc Thesis. The University of Hong Kong.

Lardinois, I, \& Van de Klunder, A. 1995.Plastic Waste. Netherlands. Tools Publications and waste consultants.

Ministry of Housing and Local Government (MHLG) 2003.Overview of solid waste management in Malaysia, Kuala Lumpur.

Wai, Ko-chi . 2007. Reduce, Reuse and Recycle. http://waikc.blogspot.com/2007/06/reducereuse-recycle.html. P 1-9 (26 June 2007).

Waite, R. 1995. Household Waste Recycling,London: Earthscan Publications Ltd.

Yahaya, N. 2007a. Solid waste management: Conference on climate change preparedness. National Solid Waste Department. Kuala Lumpur. 11 September.

Yassin, S.M. 2006. Waste Management Conference, Ministry of Local Government and Housing Kuala Lumpur 16 May 20 